\title{
THE PRINCIPLE OF PROPORTIONALITY IN VALUE ADDED TAX
}

\author{
ARTUR MUDRECKI
}

\begin{abstract}
The principle of proportionality in tax law has a normative character. At the same time, the principle under analysis is of a stipulate nature and should exert significant influence on legislative processes in the construction of a tax system. Standards developed in legal scholarship regarding the principle of proportionality, particularly a test designed to fulfill standards, can be used in the science of tax law. The principle of proportionality is a significant tool employed in the interpretation of tax law applied by the Court of Justice of the European Union and the Polish Constitutional Tribunal. Undoubtedly the case law of the Court of Justice of the European Union and the Polish Constitutional Tribunal impacts the case law of the Polish Supreme Administrative Court in the interpretation of provisions of tax law within the scope of application of the principle of proportionality.
\end{abstract}

\section{Keywords}

Proportionality; value-added tax; Poland

JEL Classification: K19, K34, K49

\section{Introduction}

The objective of the article is to attempt at answering the question of what role is played by the principle of proportionality in value-added tax. This primary objective

1 Doctor, is a professor in the Department of Financial and Tax Law, Kozminski University and a judge of the Supreme Administrative Court in Poland, Head of the Tax Law Department in the Judicial Decisions Bureau of the Supreme Administrative Court. He is also a member of the Fiscal Association Polish Branch and the International Association Centre for Information and Organization of Research on Public Finances and Tax Law of the Countries of Central and Eastern Europe - Association at the Bialystok University, European Association of Tax Law Professors, Faculty of Law and the Financial Law Association AURES in Opole. He specializes in tax law and is an author of over 100 publications, mainly on tax law. Particularly noteworthy is his monograph "Due process in tax proceedings". Contact email: amudrecki@kozminski.edu.pl. 
will be achieved by achieving detailed objectives, understood as finding answers to the following questions:

1. Does the Polish legislator, in the selection of tax law solutions, take the principle of proportionality into account?

2. Does the Court of Justice of the European Union, in issues of value added tax law, employ the analyzed European standard, and are Polish solutions compliant with this European standard?

3. Does the Polish Constitutional Tribunal, in interpreting provisions of tax law, frequently invoke the principle of proportionality?

4. Does the case law of the Polish Supreme Administrative Court, in its interpretation of tax law provisions, employ the principle of proportionality, and do judgments of the Court of Justice of the European Union and Polish Constitutional Tribunal exert the significant impact on the case law of administrative courts in Poland?

The principle of proportionality in tax law is one of the most important principles of law in respect of the rights of the taxpayer, and one of the fundamental general principles of EU law. It should also be pointed out that the indicated standard is strongly anchored in the Constitution of Poland and the case law of the Constitutional Tribunal. It impacts the interpretation applied by the Supreme Administrative Court, which employs a pro-EU and pro-constitutional approach.

The issue of the principle of proportionality has been the object of scientific study in other areas of law, e.g. in the theory of state and law, constitutional law, criminal law, civil law, European law, administrative law, and banking law (Korycka-Zirk, 2012; Szymaniec, 2015; Jasiewicz et al.: 2014). On the other hand, the principle of proportionality in tax law is a subject which has not been explored or elaborated in the scholarly literature. the previous sporadic manifestations in the Polish scholarly literature of legal dogmatic interest in the principle of proportionality in tax law were most generally provoked by controversial rulings of administrative courts, the Constitutional Tribunal, and the Court of Justice of the European Union (LasińskiSulecki, 2016: 46; Lasiński-Sulecki, 2012: 41; Brzeziński, 2014: 10; Brzeziński et al.: 2014: 325; Mączyński, 2017: 88; Etel, Pietrasz, 2011: 32).

In addition, some scholarly works have addressed the case law of the Polish Constitutional Tribunal (Selera 2017: 48; Pomorska et al.: 2011: 139). Some works have been devoted to the analysis of the case law Court of Justice of the European Union (Mikuła, 2014: 31; Mikuła, 2014; Selera, 2013: 77; Litwińczuk, 2011: 557). There have also been individual articles regarding particular tax law institutions concerning their consistency with the principle of proportionality (Kucia-Guściora et al.: 2015: 53). 


\section{Notion of Principle of Proportionality}

\subsection{Notion and Types of Principles of Law}

Before defining the notion of the principle of proportionality, we should indicate the types of principles of law. The term "principles of law" refers to delineating and explaining the sense or character of standards which can be used in the formation of various aspects of particular legal institutions within a system of law, or even entire groups of legal institutions within a system of law (stipulative character). The term "principles of law" is also used to denote norms which, because of their content, are of particular significance in the legal system in force (normative character) (Gomułowicz, Mączyński, 2016: 11).

Principles can have a normative form, or may merely find their expression in scholarship or case law. Normative principles are expressed expressis verbis in tax law provisions. Scholarly principles are an expression of the views of scholars on the shape and functioning of institutions of tax law, particular taxes, and even the tax system in its entirety. In turn, case law principles reflect the position of the judiciary in particular and more or less specific issues, particularly associated with the interpretation of the law (Brzeziński, 2015: 6).

The principle of proportionality appears as a normative and scholarly principle. These principles may impact the case law of the Court of Justice of the European Union, the Polish Constitutional Tribunal, and the Supreme Administrative Court in the interpretation of the provisions of tax law.

\subsection{Principle of Proportionality in Normative Sense}

In the normative sense, the legal basis of the principle of proportionality jest Art. 3b (3 and 4), incorporated into the Treaty on European Union and Treaty Establishing the European Community by the Lisbon Treaty, replacing Arts. 5/4-5) of the Treaty on European Union. Under the adopted solutions and under the principle of subsidiarity, in areas which do not fall within its exclusive competence, the Union shall act only if and in so far as the objectives of the proposed action cannot be sufficiently achieved by the Member States, either at central level or at regional and local level, but can rather, by reason of the scale or effects of the proposed action, be better achieved at Union level. The institutions of the Union shall apply the principle of subsidiarity as laid down in the Protocol on the application of the principles of subsidiarity and proportionality. National Parliaments ensure compliance with the principle of subsidiarity in accordance with the procedure set out in that Protocol (Art. 3b/3). Under the principle of proportionality, the content and form of Union action shall not exceed what is necessary to achieve the objectives of the Treaties. 
The institutions of the Union shall apply the principle of proportionality as laid down in the Protocol on the application of the principles of subsidiarity and proportionality (Art. 3b/4).

Concerning the application of the principles of subsidiarity and proportionality, the Protocol holds that Each institution shall ensure constant respect for the principles of subsidiarity and proportionality, as laid down in Art. 5 of the Treaty on European Union (Art. 1 of the Protocol). The Commission shall forward its draft legislative acts and its amended drafts to national Parliaments at the same time as to the Union legislator. The European Parliament shall forward its draft legislative acts and its amended drafts to national Parliaments (Art. 4 of the Protocol). The Court of Justice of the European Union shall have jurisdiction in actions on grounds of infringement of the principle of subsidiarity by a legislative act, brought in accordance with the rules laid down in Art. 263 of the Treaty on the Functioning of the European Union by the Member States, or notified by them in accordance with their legal order on behalf of their national Parliament or a chamber thereof. In accordance with the rules laid down in the said Article, the Committee of the Regions may also bring such actions against legislative acts for the adoption of which the Treaty on the Functioning of the European Union provides that it be consulted (Art. 8 of the Protocol). The Commission shall submit each year to the European Council, the European Parliament, the Council and national Parliaments a report on the application of Art. 5 of the Treaty on European Union. This annual report shall also be forwarded to the Economic and Social Committee and the Committee of the Regions (Art. 9 of the Protocol).

Under the principle of proportionality, the scope and form of action by the European Union may not exceed that which is necessary for accomplishing the objectives of the Treaty. This principle is a criterion for the activities of EU institutions and is also the basis for assessing actions taken by Member States (Militz et al.: 2013: 145146).

The principle of proportionality was set out in Art. 31/3 of the Constitution of the Republic of Poland of 2 April 1997. This provision establishes that any limitation upon the exercise of constitutional freedoms and rights may be imposed only by statute, and only when necessary in a democratic state for the protection of its security or public order, or to protect the natural environment, health or public morals, or the freedoms and rights of other persons. Such limitations shall not violate the essence of freedoms and rights.

The principle of proportionality is assigned a different meaning in respect of Value Added Tax (VAT). Under Art. 1/2 of the Directive 112 (Council Directive 2006/112/ $\mathrm{EC}$ on the common system of value added tax), the principle of the common 
system of VAT encompasses the application of a general consumption tax exactly proportional to the price of goods and services, irrespective of the number of transactions which occur in the production and distribution process prior to the stage at which the tax is collected. And thus, the principle of proportionality influences the determination of the appropriate tax base (Militz et al.: 2013: 96). The principle of proportionality resulting from Art. 1/2 of the 112 Directive exceeds the scope of this article. This does not, however, mean that the principle of proportionality in a broader sense does not apply in the interpretation of provisions concerning value added tax.

\subsection{Principle of Proportionality in Scholarship}

In the theory of law, R. Alexy points out that there is a direct link between the theory of principles and the principle of proportionality. According to German legal doctrine, the principle of proportionality is described as the relation of the (applied) means to the (intended) objective. This relation, however, should comply with three sub-rules. These criteria, which can be considered a type of test, include the criteria of:

1. usefulness,

2. necessity,

3. proportionality sensu stricto.

The criterion of usefulness is fulfilled when a given measure is useful in achieving a given objective, id est by using that measure it is possible to achieve a stated goal. However, this goal must be legitimized, id est it must be consistent with legally protected values.

The criterion of necessity is fulfilled when a given measure is necessary for achieving a given objective (id est there is no measure which could achieve the stated goal with the same effectiveness, and which would simultaneously be more benign in its effects on legally protected values, principles, objectives).

The criterion of proportionality sensu stricto, in turn, is satisfied when the number of benefits of a given measure is greater than the number of drawbacks; when the balance of a good (value) protected and the good sacrificed is positive; when applied measures are justified by the "weight and nature" of the objective they are to serve, when the proper relationship exists between the benefits derived from achieving the assumed goal and the injury done to a constitutional right resulting from the fact of that objective being achieved (Alexy, 2002: 66; Korycka-Zirk, 2012: 130; Mikuła, 2014: 38). 
In another definition, the principle of proportionality is associated with restraint in the activities of public authorities and minimizing their interference in rights and freedoms. The principle of proportionality is referred to as the principle of commensurability, of restraint, and of adequacy (Etel, Pietrasz, 2012: 27). An adequate comparison of the application of the principle of proportionality is to say that one should not shoot from a cannon in order to hit a sparrow.

\section{Assessment of Application of Principle of Proportionality in Legislative process}

The addressees of the principle of proportionality are the legislative authority, the executive authority, the judiciary. The principle of proportionality as a stipulatory principle of law should be taken into consideration when constructing a tax law system. The analyzed principle takes on a particular significance when considering the fact that it is of a normative character and constitutes both an EU and constitutional standard.

Certain doubts regarding observance of the principle of proportionality are raised by some legislative solutions in effect. The Act of 10 February 2017 on amending the Act - the Criminal Code and other acts introduced a new qualified offence associated with the falsification of invoices and using them for tax-related purposes. Article 270a Criminal Code sets out a punishment of 6 months to 8 years of imprisonment. If the value of the invoices exceeds PLN 5,000,000 or the crime served the perpetrator as a regular source of income, the crime is classified as a qualified offense, and criminal liability then increases to imprisonment from 3 to 8 years. Similar sanctions are set out in Art. 271 Criminal Code for issuing and using invoices in value-added tax. Even harsher penalties are set out in Art. 277a/1 Criminal Code. Under this provision, for commission of the offense set out in Art. 270a/1 or Art. 271a/1 in respect of an invoice or invoices the sum of whose receivables exceeds a figure ten times that which defines property of great value, the potential term of imprisonment is between 5 and 25 years. And thus, if the value of the invoices exceeds PLN 10,000,000, criminal liability can be as great as 25 years of imprisonment: the perpetrator can be given one of the harshest sentences short of lifetime imprisonment. The cost of carrying out such a sentence is PLN 950,000. The question thus arises: will the general preventative objective of these provisions be fulfilled? We may take an example from the history of law reaching back to the Middle Ages, when execution was the punishment for pickpocketing, applied as a way of eliminating the plague of theft. However, during public executions, other thieves pickpocketed the assembled onlookers. This demonstrated that even a very harsh punishment is insufficient to scare people off of committing crimes, as their 
perpetrators do not imagine they can be caught. Similar conclusions can be drawn in respect of adopted legal solutions. Even very harsh penalties are unable to prevent the commission of crimes associated with forging and using the VAT invoices. The procedure for issuing so-called "empty invoices" involves people who are homeless, mentally unstable, or terminally ill as fronts. And thus, those harsh punishments will not be meted out to those who receive the greatest benefits from VAT fraud as its organizers. The most effective means of prevention in respect of such crimes is their effective discovery and inevitability of punishment.

It would also seem that the legal solutions which have been introduced are inconsistent with the principle of proportionality, as they do not meet the three criteria set out in the test. Firstly, in light of the arguments presented above, it is not known whether the applied measure can prevent VAT fraud. Secondly, the application of such harsh punishments is unnecessary in light of the introduction of the mechanisms of the Unitary Control File, reverse charges, split payment of VAT, and the sanctions envisioned in provisions related to the tax, such as for submitting false tax filings, for failure to register turnover in cash registers, and responsibility for "empty invoices" (Art. 108 VAT Act). The indicated measures would seem sufficient to limit abuses associated with VAT fraud. Ultimately, the introduction of long-term imprisonment, in principle equivalent to those for crimes against human health and life, is in contradiction with the principle of proportionality sensu stricto. Even the justified protection of the interests of the State Treasury cannot justify long-term prison sentences. In addition, the financial and social costs of carrying out such a punishment can be exceedingly high. In such a situation, the punishment is inadequate to the crime committed.

\section{Impact of Principle of Proportionality on Case Law of Court of Justice of European Union}

Principles of law can come in jurisprudential form. It cannot be said that the principle of proportionality fulfills the conditions for it to be recognized as jurisprudential doctrine. Nevertheless, it plays an important role in the interpretation of tax law provisions. In the process of interpreting tax law, three directives of interpretation are generally employed: linguistic interpretation, systemic interpretation, and functional interpretation. Additionally, pro-EU interpretation (interpretation favorable to European law) and pro-constitutional interpretation (interpretation consistent with the provisions of the Constitution) are applied. The principle of proportionality as applied in the decisions of international courts, constitutional tribunals, and municipal courts can be considered pro-EU and/or pro-constitutional. 
This is a sort of second-level interpretation supplementary to the primary interpretative principles.

The Court of Justice of the European Union (CJEU) plays an important role in respect of protection of the rights of the taxpayer. On the one hand, it refers in its case law to the standards for human rights protection developed by the European Court of Human Rights within the framework of amicable cooperation, while on the other it does so through the application of pro-EU interpretation, binding on national courts and effectively protecting the rights of the taxpayer. Here it should be emphasized that the CJEU deals with the tax matter, particularly ones concerning taxes subject to harmonization, such as VAT and excise tax (Mudrecki, 2015: 79).

The Court of Justice of the European Union relatively frequently employs the principle of proportionality in the interpretation of European law. In its verdict (CJEU: C-25/07) in the A. Sosnowska case, the CJEU held that Art. 18/4 of the Six Directive 77/388 is inconsistent with domestic regulation which - intending to facilitate the oversight necessary to prevent tax avoidance and fraud - extends from 60 to 180 days (from the day of filing by taxpayers of specified categories of a VAT submission) the period within which a national tax authority may refund surplus VAT payments in the absence of a substantial bond.

The pro-EU interpretation undertaken with regard to infringement of the principle of proportionality, as an EU standard, led to the conclusion that Polish solutions concerning the extension of the right to a VAT refund are overly restrictive, and thus in conflict with EU law. Thus, they demand changes in order to achieve full harmonization of the provisions of tax law. Characteristically, the Court of Justice of the European Union, alongside the principle of proportionality, invokes with the relative frequency the principle of neutrality as a foundation of the value-added tax.

The Court of Justice of the European Union in another verdict (CJEU: 564/15) in the case Tibor Farkas v. Nemzeti Adó-és Vámhivatal Dél-alföldi Regionális Adó Föigazgatósága held as appropriate the loss of the right to claim a deduction in the case of acquisition of goods subject to reverse charge, and pointed to disproportionality in VAT sanctions. In the case under consideration, the purchaser of the goods was deprived of the right to deduct the VAT they had wrongly paid the seller on the basis of an invoice drawn up in accordance with the ordinary VAT regime, where the relevant transaction was subject to the reverse charge mechanism and the seller had remitted the tax to the Treasury. In this ruling, it was pointed out that the provisions of Directive 2006/112, amended via Directive 2010/45, and the principles of fiscal neutrality, effectiveness and proportionality must be interpreted to the effect that, in a situation such as that in the main proceedings, they do not preclude the purchaser of an item of property from being deprived of the right to 
deduct the VAT which he paid to the seller when that tax was not due, on the basis of an invoice drawn up in accordance with the rules of the ordinary VAT regime, where the relevant transaction came under the reverse charge mechanism, and the seller paid that tax to the Treasury. However, if reimbursement of the VAT becomes impossible or excessively difficult, in particular in the case of the insolvency of the seller, the principle of effectiveness may require that the purchaser of the property concerned be able to address his application for reimbursement to the tax authority directly. The principle of proportionality must be interpreted to the effect that it precludes national tax authorities, in a situation such as that in the main proceedings, from imposing on a taxable person, who purchased an item of property the transfer of which comes under the reverse charge regime, a tax penalty of $50 \%$ of the amount of VAT which he is required to pay to the tax authority, where that authority suffered no loss of tax revenue and there is no evidence of tax evasion, this being a matter for the referring court to determine.

Doubtlessly, the principle of proportionality has the significant influence on imposing tax sanctions when the Hungarian Treasury suffered no injury, as the value-added tax due had been paid. Interestingly, the Court of Justice of the European Union denied the right to deduct the assessed tax on the purchaser of goods when the reverse charge mechanism was not applied. However, the Court did indicate that a taxpayer experiencing difficulty in pursuing claims against an insolvent counterparty may apply to the tax authority for a refund.

\section{Principle of Proportionality in Case Law of the Polish Constitutional Tribunal}

The Polish Constitutional Tribunal has relatively frequently taken up the issue of the principle of proportionality. Doubtlessly, the principle of proportionality is one of the most important constitutional standards. Under Art. 8 of the Constitution of Poland, the Constitution is the supreme law of the Republic of Poland. The provisions of the Constitution shall apply directly unless the Constitution provides otherwise. Any limitation upon the exercise of constitutional freedoms and rights may be imposed only by statute, and only when necessary in a democratic state for the protection of its security or public order, or to protect the natural environment, health or public morals, or the freedoms and rights of other persons. Such limitations shall not violate the essence of freedoms and rights. Therefore, every change of legal regulations should consider the necessity of observing the principle of proportionality and impact the legislative process, yet should also influence the interpretation of law applied not only by the Polish Constitutional Tribunal but also 
administrative courts and tax authorities. In determining the constitutionality of legal acts, the Polish Constitutional Tribunal is bound by the constitutional model.

The charge of breaching the principle of proportionality is not always accepted. The Polish Constitutional Tribunal In its verdict of 8 October 2013 (no: SK 40/12), held that Art. 33/2/2 in conjunction with Art. 33/1 of the Tax Ordinance Act of 29 August 1997 as it stood during the period from 1 January 2003 to 31 August 2005, insofar as it made the impounding of tax arrears in the course of audit proceedings dependent on the "justified concern" that a tax obligation would not be performed, was compliant with Art. 45/1 and Art. 64/3 in conjunction with Art. 2 and Art. 31/3 of the Polish Constitution.

However, in many cases, the Tribunal has ascertained a breach of the principle of proportionality. In its verdict of 21 July 2010 (no. SK 21/08) the Polish Constitutional Tribunal held that Art. 72/1/1 in conjunction with Art. 77/1 an Art. 77/2/1 of Tax Ordinance Act of 27 August 1997, in respect of its wording in effect until 4 June 2001, within the scope in which that provision, by determining as an overpayment the sum of overpaid or unduly paid tax with the omission of the sum of unduly paid interest for late payment, deprives the taxpayer of interest on the sum paid in lieu of interest for late payment on unpaid tax arrears paid on the basis of an unlawful tax decision, is incompatible with Art. 77/1 and Art. 64/1 in conjunction with Art. 31/3 of the Polish Constitution.

In the justification to the ruling, the Tribunal recalled that the essence of the regulation contained in Art. 31/3 of the Constitution is an establishment of the preconditions that must be fulfilled in order to impose restrictions on constitutional rights and freedoms. The referenced oversight model establishes as a general principle exclusively statutory grounds for limitation or suspension of rights and freedoms, while simultaneously formulating the restriction that such a limitation can only take place when it is necessary in a democratic state, to ensure the security of the state and/or public order, to protect the environment, public health and morality, or the rights and freedoms of others. These regulations also include in the second sentence a restriction that such limitations cannot violate the essence of rights and freedoms. The Polish Constitutional Tribunal has pointed out on multiple occasions that any and all limitations on the exercise of constitutional rights and freedoms must take account of Art. 31/3 of the Constitution (see judgments P.11/98, P.23/00, P.30/07). The scope of regulation in Art. 31/3 is of a universal character, as it applies to all constitutional rights and freedoms.

The association between statutory limitation on constitutional freedoms and rights of the individual and protection of one of the values enumerated in Art. 31/3 of the Polish Constitution is the necessary condition of ascertaining the permissibility of 
its enactment. The scope of this limitation - pursuant to the first sentence of Art. $31 / 3$ of the Polish Constitution - must satisfy the principle of proportionality, which expresses the conviction that the extent of interference in the legal situation of an individual must be justified by the rank of the public interest protected thereby. In other words, a limitation on the rights of the individual must be appropriate to the object it is intended to serve, and rational. To determine whether in a given case the interference is not excessive, it is necessary to find answers to three questions: Can the adopted legislation actually achieve the intended effects? Is the regulation vital to the protection of the given constitutional value? Are the effects of the adopted regulation proportional to the burdens it imposes on the citizen? (proportionality sensu stricto) (see verdict K.19/01).

In another verdict (SK.14/12), the Polish Constitutional Tribunal ruled that $\S 6 / 5$ in conjunction with $\S 5 / 1$ as worded effective 1 January 2003, and with $\S 12 / 1 / 1$ of the Regulation of the Minister of Finance of 22 March 2002 on Excise tax within the scope it affects cases of unaware acceptance by the seller of a declaration on the destination of purchased fuel oil for heating purposes that contains false information, is incompatible with Art. 64/1 and 3 in conjunction with Art. 2 and Art. 31/3 of the Constitution of Poland. In the text of the decision, it was indicated that the discretion enjoyed by the legislator does not, however, Authorize it to establish conditions impossible for the taxpayer to fulfill. In particular, this entails a violation of the principle of the individual's trust in the state and the law enacted by it, as well as of the principle of prohibition on disproportionate interference in the taxpayer's property rights, associated with the necessity of paying a higher tax bill as a result of the impossibility of taking advantage of preferential tax regulations. It should, however, be emphasized that this impossibility results from conditions which the taxpayer has no influence over.

In a successive verdict (SK.2/10), the Polish Constitutional Tribunal held that Art. 31/1 of the Tax Audit Act of 28 September 1991, as established by the Act of 27 June 2003 on the creation of Provincial Tax Councils and amendments to some other Acts regulating the tasks and competencies of organs and the organization of authorities overseen by the minister responsible for matters of public finance, within the scope in which it excludes the relevant application of Art. 54/1/1 and 7 of the Tax Ordinance Act of 27 August 1997 is incompatible with Art. 84 in conjunction with Art. 641 and 2), Art. 31/3, Art. 32/1 and Art. 2 of the Constitution of Poland.

In the text of the verdict, it was emphasized that in the case at hand - reconstructing the content of the audit standard - Art. 31/3 of the Polish Constitution can also be invoked, as the charge concerns not an interference in property rights consisting in the assessment of a tax, but interference in property rights via additional burdens exceeding the borders of the tax itself. However, with consideration to 
the invocation of Art. 2 of the Constitution, the Polish Constitutional Tribunal reminds us that the principle of proportionality has a broader meaning, as it refers in general to situations in which the state enacts legislation impacting the position of an individual under its authority. In these situations, the charge of the absence of proportionality is assessed without reference to the intersection with a subjective constitutional right (e.g. K.20/01; K.8/07; K.66/07). The Polish Constitutional Tribunal derived three interrelated obligations from the principle of proportionality imposed on the lawmaker: 1) enacting a given regulation only when it is essential to the protection of the public interest associated with it, 2) fashioning a given regulation in a manner that ensures the achievement of the intended objectives (effects), 3) maintaining proportion between the effects of the adopted regulation and the burdens and/or disadvantages for citizens resulting from it. This principle places particular emphasis on adequacy of the objective and the measure employed to achieve it. In other words, from among the potential measures for exerting influence, it is required to select those which would be at once effective in achieving the assumed objectives while imposing the least possible burden on the entities against which it is to be applied, or burdensome to a degree not greater than is necessary for achieving the intended objective.

The rule adopted in the questioned regulation concerning the assessment of interest for tax arrears including also the period during which the performance of the tax obligation was secured against the assets of the taxpayer, when the funds acquired from the security are booked against tax arrears, and for the period starting from the day on which audit proceedings were initiated until the day on which a decision of the organ of the first instance was issued and that decision was not served within 3 months of the day on which the audit proceedings were initiated, puts taxpayers under audit by tax authorities in a worse legal situation than taxpayers under audit by tax authorities against whom interest for those periods is not assessed.

The differentiation present in the questioned provision of the legal situation of taxpayers depending on which tax authority they are being audited by is unjustified, and must be held as an arbitrary choice of the lawmaker. By the same token, the questions regulation places taxpayers under audit by tax audit organs in a worse situation, by depriving them of the right to not have interest assessed for the period during which their assets were secured against tax arrears. There are no grounds to state that such a distinction was justified by the necessity to realize an important public interest. From the presented example verdicts of the Polish Constitutional Tribunal, we may conclude that the three criteria previously developed in the legal scholarship are to be applied in assessing whether the principle of proportionality has been violated. 


\section{Influence of Principle of Proportionality on Interpretation of Provisions of Tax Law in Case Law of Supreme Administrative Court}

The principle of proportionality influences the case law of administrative courts. A certain model for carrying out interpretation of tax law provisions can be found in the case law Court of Justice of the European Union and of the Polish Constitutional Tribunal. It should be emphasized here that it is incumbent upon national courts to apply pro-EU interpretation due to the primacy it enjoys. Pro-constitutional interpretation is also necessary with consideration to the fact that the Constitution is the supreme law of the Republic of Poland. It thereby holds an important place in the interpretation of legislative provisions.

The Supreme Administrative Court in its verdict (I FSK 1278/15), held that for refusal of registration to be considered proportional in respect of an object consisting in preventing tax fraud, it must be based on serious considerations permitting the objective ascertainment of a likelihood that registration of a VAT taxpayer will be abused for purposes of fraud. Such a decision must be based on a comprehensive assessment of all circumstances of a given case, and on evidence collected to verify information supplied by the enterprise.

In its justification, the Court invoked the view expressed in the judgement of the Court of Justice of the European Union (CJEU: C-527/11) in the Ablessio case, in which the latter Court indicated that the measures applied by a state may not exceed what is necessary to achieve the selected objectives, and furthermore they may not undermine the right to deduction, and by the same token neutrality of the tax.

In another verdict, the Supreme Administrative Court (I FSK 1916/15), held that Art. 88/3a/4/b of the VAT Act of 11 March 2004, pursuant to which issued invoices, corrective invoices, and customs documents containing false sums do not constitute grounds for claiming deductions - in respect of those items for which false sums were given - should be interpreted in such a manner that, if the evidence gathered gives the tax authority the possibility to determine the real value of the transaction captured in the inflated sum on the invoice, the taxpayer - with consideration to the principles of neutrality and proportionality - has the right to deduct the tax to the extent it expresses the real value of the transaction.

In another verdict, the Supreme Administrative Court (1536/13), held that in the case of a taxpayer who - having fulfilled all of the conditions set out in Art. 89a/2 of the VAT Act of 11 March 2004 as in effect through 31 December 2012 - submitted a correction to the tax due in an incorrect accounting period, a corrective filing submitted pursuant to the mode set out in Art. 81/1 of tax Tax Ordinance Act of 27 
August 1997 in order to remedy the defect and settle the corrected tax due under Art. 89a/1 VAT Act in the proper accounting period indicated in Art. 89a/3 VAT Act is not limited by the term set out in Art. 89a/2/5 VAT Act, as no fraud nor injury to the state budget.

In a subsequent verdict, the Supreme Administrative Court (I FSK 709/12) indicated that interpretation of Art. 116/6/2 of the VAT Act cannot lead to the violation of the following principles: neutrality of VAT, proportionality as defined under Art. 31/3 in conjunction with Art. 2 Constitution of Poland and Art. 5 Treaty on European Union, and protection of property rights as defined under Art. 21/1 in conjunction with Art. 64/1 Constitution of Poland. In other words, that provision should be interpreted so that the taxpayer remitting a late payment to a flat-rate farmer for acquired products or services and encompassing flat-rate tax refund is not deprived of the right to receive that refund.

\section{Conclusions}

The principle of proportionality in tax law has a normative character. At the same time, the analyzed principle is of a stipulative nature, which should exert significant influence on legislative processes shaping the tax system. The standards developed in legal scholarship concerning the principle of proportionality, and particularly the test serving the fulfillment of standards, can be used in the science of tax law.

The research results presented in this work allow us to formulate the following initial research hypotheses:

1. The principle of proportionality plays a significant role in value-added tax.

2. In the selection of tax solutions, the Polish lawmaker takes insufficient account of the principle of proportionality, which leads to those solutions being incompatible with EU and Constitutional regulations. The adopted solutions are inadequate to the intended effects, at times shooting from a cannon at a sparrow.

3. In tax cases, the Court of Justice of the European Union relatively frequently applies the principle of proportionality alongside other EU principles, in order to ensure the protection of taxpayers' rights. Particularly important rulings concerning the principle of proportionality have been handed down in Polish cases.

4. The Polish Constitutional Tribunal, in interpreting provisions of tax law, frequently invokes the principle of proportionality. The case law of the Polish Constitutional Tribunal influences legislative practice. 
5. The Supreme Administrative Court, in interpreting provisions of tax law, applies the principle of proportionality. The case law of Polish administrative courts is significantly influenced by verdicts of the Court of Justice of the European Union and the Polish Constitutional Tribunal.

\section{References}

Alexy, R.: A Theory of Constitution Rights, Oxford: Oxford University Press, 2002.

Brzeziński, B.: Glosa do wyroku NSA z dnia 17 maja 2013 r. II FSK 1812/11 (Gloss to ruling of SAC of 17 May 2013 II FSK 1812/11), Orzecznictwo Sądów Polskich (Jurisprudence of Polish Courts) no. 2014/1/10 (2014).

Brzeziński, B., Lasiński-Sulecki, K., Morawski, W.: Oświadczenia nabywców oleju opałowego i zestawienia tych oświadczeń a zasada proporcjonalności (Declaration of purchasers of fuel oil, juxtaposition of those declarations and the principle of proportionality), Przegląd Orzecznictwa Podatkowego (Review of Tax Case Law) no. 4 (2014).

Brzeziński, B.: Zasady ogólne prawa podatkowego (General principles of tax law), Toruński Rocznik Podatkowy (Toruń Annual Fiscal Journal) no. 4 (2015).

Etel, L., Pietrasz, P.: Uwagi w przedmiocie konstytucyjności art. 89 ust. 16 ustawy o podatku akcyzowym (Remarks on the constitutionality of Art. 89/16 of the Excise Tax Act), Przegląd Podatkowy (Tax Review) no. 10 (2011).

Etel, L., Pietrasz, P.: Niekompletność świadczeń o przeznaczeniu oleju opałowego a zastosowanie sankcji podatkowej, o której mowa w art. 89 ust. 16 u.p.a. (Incompleteness of declarations on the destination of fuel oil and application of a tax sanction as provided for in Art. 89/16 Excise Tax Act), Zeszyty Naukowe Sądów Administracyjnych (Scholarly Journal of Administrative Courts) no. 2 (2012).

Gomułowicz, A., Mączyński, D.: Podatki i prawo podatkowe (Taxes and tax law), Warszawa: Wolters Kluwer, 2016.

Gomułowicz, A.: Zasada proporcjonalności w orzecznictwie Trybunału Konstytucyjnego a obowiązek podatkowy (The principle of proportionality in the case law of the Constitutional Tribunal and the tax obligation), in: Pomorska, A., Smoleń, P., Stelmasiak, J., Gorgol, A. (eds.): Prawo finansowe w warunkach członkostwa Polski w Unii Europejskiej. Księga jubileuszowa dedykowana Profesor Wandzie Wojtowicz (Financial law in conditions of Poland's membership in the European Union. Anniversary book dedicated to Professor Wanda Wojtowicz), Lublin: Wydawnictwo UMCS, 2011.

Jasiewicz, S., Kulikowski, L., Szpringer, W. (eds.): Zasada proporcjonalności. Przełom w ocenie regulacji (The principle of proportionality. A breakthrough in assessment of regulation), Warszawa: GBPiZS, 2014.

Korycka-Zirk, M.: Teorie zasad prawa a zasada proporcjonalności (Theories of princniples of law and the principle of proportionality), Warszawa: LexisNexis, 2012.

Kucia-Guściora, B., Münnich, M., Zdunek, A. (eds.): Michna, E.: Zasada proporcjonalności w wykładni przepisów dotyczących sankcji podatkowych w świetle orzecznictwa TSUE, 
TK oraz sądów administracyjnych (The principle of proportionality in interpretation of provisions concerning tax law sanctions in light of case law of the CJEU, CT, and administrative courts), in: Stanowienie i stosowanie prawa podatkowego w Polsce. Sankcje i preferencje w prawie podatkowym, (Enacting and applying tax law in Poland. Sanctions and preferences in tax law), Lublin: Wydawnictwo KUL, 2015.

Lasiński-Sulecki, K.: Glosa do wyroku TS z dnia 2 czerwca 2016 r., C-418/14 (Gloss to ruling of CJEU of 2 June 2016, C-418/14), Przegląd Podatkowy (Tax Review) no. 9 (2016).

Lasiński-Sulecki, K.: Glosa do wyroku TS UE z 26 stycznia 2012 r. C-588/10 (Gloss to ruling of CJEU of 26 January 2012 C-588/10), Przegląd Podatkowy (Tax review) no. 3 (2012).

Mączyński, D.: Glosa do uchwały NSA z dnia 24 października 2016 r. I FPS 2/16 (Gloss to SAC resolution of 24 October 2016 I FPS 2/16), Orzecznictwo Sądów Powszechnych (Common Court Rulings) no. 1 (2017).

Mikuła, P.: Zasada proporcjonalności w orzecznictwie TSUE dotyczących podatku od wartości dodanej (The principle of proportionality in the case law of the CJEU as concerns value added tax), Kwartalnik Prawa Podatkowego (Quarterly of Tax Law) no. 2 (2014).

Mikuła P.: Zasada proporcjonalności w podatku od wartości dodanej - analiza orzecznictwa TSUE (The principle of proportionality in value added tax - analysis of CJEU case law), Toruński Rocznik Podatkowy (Toruń Annual Fiscal Journal) no. 2 (2014).

Militz, M., Dominik-Ogińska, D., Bącal, M., Siennicki, T.: Zasady prawa unijnego (Principles of EU law), Warszawa: Wolters Kluwer Polska, 2013.

Mudrecki, A.: Rzetelny proces podatkowy (Fair tax proceedings), Warszawa: Wolters Kluwer, 2015.

Selera, P.: Decyzje wykonawcze Rady odnoszące się do podatku od towarów i usług a traktatowa zasada proporcjonalności (Enforcement decisions of the Council referring to value added tax and the treaty principle of proportionality), Kwartalnik Prawa Podatkowego (Tax Law Quarterly) no. 2 (2013).

Selera, P.: Wpływ unijnej zasady proporcjonalności na polskie regulacje w zakresie podatku od towarów i usług (Impact of the EU principle of proportionality on Polish regulations concerning value added tax), in: Litwińczuk, H. (ed.): Prawo europejskie - 5 lat doświadczeń w polskim prawie finansowym (European law -5 years of experience in Polish financial law), Warszawa: Oficyna Prawa Polskiego, 2011.

Selera, P.: Zasada proporcjonalności w orzecznictwie podatkowym Trybunału Konstytucyjnego (The principle of proportionality in the tax case law of the Constitutional Tribunal), Państwo i Prawo (The state and the law) no. 4 (2017).

Szymaniec, P. (ed): Zasada proporcjonalności a ochrona praw podstawowych w państwach Europy (The principle of proportionality and protection of fundamental rights in the states of Europe), Wałbrzych: Państwowa Wyższa Szkoła Zawodowa w Wałbrzychu, 2015.

EU: Council Directive 2006/112/EC on the common system of value added tax.

EU: Court of Justice of the European Union: no. C- 527/11.

EU: Court of Justice of the European Union: no. C-25/07. 
EU: Court of Justice of the European Union in another verdict: no. CJEU: 564/15.

PL: Act of 10 February 2017 on amending the Act - the Criminal Code and other acts.

PL: Tax Ordinance Act of 27 August 1997, as amended.

PL: Regulation of the Minister of Finance of 22 March 2002 on Excise tax.

PL: Regulation of the Minister of Finance: no. 3/2002 on Excise tax.

PL: Tax Audit Act of 28 September 1991, as amended.

PL: Constitutional Tribunal: SK.40/12.

PL: Constitutional Tribunal: SK.21/08.

PL: Constitutional Tribunal: P.11/98.

PL: Constitutional Tribunal: K.23/00.

PL: Constitutional Tribunal: P.30/07.

PL: Constitutional Tribunal: K.19/01.

PL: Constitutional Tribunal: SK.14/12.

PL: Constitutional Tribunal: SK.2/10.

PL: Constitutional Tribunal: K.20/01.

PL: Constitutional Tribunal: K.8/07.

PL: Constitutional Tribunal: K.66/07.

PL: Supreme Administrative Court: I FSK 1278/15.

PL: Supreme Administrative Court: I FSK 1916/15.

PL: Supreme Administrative Court: 1536/13.

PL: Supreme Administrative Court: I FSK 709/12. 